Research Article

\title{
An experimental study on the effect of isoniazid on the efficacy, plasma concentration and toxicity of paracetamol in Albino rats
}

\author{
Navdeep Dahiya*, Sushil Sharma, Anjan Khadka, Dick S. Brashier, A. K. Gupta, A. K. Sharma
}

\author{
Department of Pharmacology, \\ Armed Forces Medical \\ College, Pune, Maharashtra, \\ India
}

Received: 09 July 2014 Accepted: 31 July 2014

*Correspondence to: Dr. Navdeep Dahiya, Email: navdeepdahiya@ rediffmail.com

Copyright: (C) the author(s), publisher and licensee Medip Academy. This is an openaccess article distributed under the terms of the Creative Commons Attribution NonCommercial License, which permits unrestricted noncommercial use, distribution, and reproduction in any medium, provided the original work is properly cited.

\begin{abstract}
Background: Paracetamol is used for symptomatic treatment of fever and pain with isoniazid and other anti-tubercular drugs in patients of tuberculosis. Literature has conflicting data regarding their interaction. Some studies show that isoniazid increases oxidative metabolism of paracetamol whereas some other suggest that isoniazid has an inhibitory effect. The present study was conducted to find out the possible interaction between paracetamol and isoniazid.

Methods: The study was undertaken on Wistar strain of Albino rats. Group I and Group II animals were treated with paracetamol $(500 \mathrm{mg} / \mathrm{kg})$ and the combination of paracetamol $(500 \mathrm{mg} / \mathrm{kg})$ and isoniazid $(30 \mathrm{mg} / \mathrm{kg})$ respectively for $2 \mathrm{months}$. Blood samples were taken before and during the study for biochemical and histopathological studies of liver and renal functions and plasma paracetamol concentration was also evaluated.

Results: Isoniazid decreased the plasma paracetamol concentration without affecting its analgesic activity. However, the hepatotoxic and nephrotoxic effects of paracetamol were found to be further aggravated by isoniazid co-administration. Conclusion: Isoniazid potentiates the hepatotoxic and nephrotoxic effects of paracetamol possibly due to hepatic enzyme induction by isoniazid.
\end{abstract}

Keywords: Efficacy, Isoniazid, Paracetamol, Toxicity

\section{INTRODUCTION}

Tuberculosis is effectively treated by combination drug therapy. First-line essential drugs are isoniazid, rifampin and pyrazinamide. First-line supplement drugs are ethambutol and streptomycin. ${ }^{1,2}$

Isoniazid, which is a key drug in the treatment of tuberculosis results in hepatitis and arthritic symptoms like back pain, arthralgia of knees, elbows, wrist and shoulder-hand syndrome on long-term therapy. ${ }^{3}$ Isoniazid is transformed into a reactive toxic metabolite in the liver. Isoniazid is first acetylated into acetyl-isoniazid, which is hydrolyzed into acetyl hydrazine. Acetyl hydrazine is believed to be either acetylated again into nontoxic diacetyl-hydrazine, or may be transformed by CYP4502E1 into a reactive acetyl radical which binds covalently to hepatic proteins. ${ }^{3,4}$ Slow acetylators are more prone to the hepatotoxic effect of isoniazid. ${ }^{5}$ About $60 \%$ of the Indian population is slow acetylators.
Paracetamol is the most commonly used and safe analgesic and antipyretic without any significant anti-inflammatory effect. ${ }^{6}$ It is most widely used for symptomatic control of fever associated with various bacterial/viral infections. Paracetamol is likely to be used as an antipyretic along with anti-tubercular drugs in the initial phase to counter the pyrexia before anti-tubercular drugs produce their effect. As a result of long-term continuation of isoniazid, its side effects like arthralgia, arthritis and fever leads to frequent use of antipyretics and analgesics. ${ }^{7,8}$ Hepatotoxic and nephrotoxic effects of paracetamol on acute overdosage or on chronic use are well-documented. The predominant pathway of paracetamol metabolism are conjugation to form phenolic, glucuronide and sulphate conjugates and microsomal oxidative pathway of metabolism that lead to both catechol and glutathione metabolites. Toxic intermediate metabolite formed by cytochrome P-450 oxidation is N-acetyl-p-benzoquinoneimine (NAPQI). NAPQI is an electrophile metabolite of the drug that binds covalently to the tissue macromolecules and probably also 
oxidizes nonprotein and protein thiols. ${ }^{6}$ Hepatic microsomal enzyme cytochrome P-450 2E1 catalyses the formation of NAPQI and it is induced by isoniazid. ${ }^{9}$ Due to increasing in oxidative metabolism of paracetamol, its hepatotoxicity may also increase. ${ }^{10}$ However, some studies suggest that isoniazid can inhibit the microsomal oxidative metabolism of paracetamol. ${ }^{6,9}$ In view of the above, so also conflicting reports on the effect of isoniazid on paracetamol metabolism, there is a possibility of an interaction of paracetamol with isoniazid that is also a hepatotoxic agent, thus may result in probable change in the pharmacokinetic profile as well as its efficacy and adverse effects. ${ }^{8,11,12}$

The present study was, therefore, undertaken to explore the possible interaction of paracetamol with the commonly used primary anti-tubercular drug isoniazid in respect to its plasma concentration, efficacy and adverse effects in Albino rats.

\section{METHODS}

Healthy adult Albino rats of either sex of Wistar strain weighing between 200 and $300 \mathrm{~g}$ were used after obtaining approval from the Institutional Animal Ethics Committee. They were housed in clean cages and were maintained on standard laboratory diet and water ad-libitum. After a 5 days acclimatization period, the rats were used for the study. They were kept under standardized animal house conditions (12 hrs light and $12 \mathrm{hrs}$ dark condition).

Isoniazid was used in a dose of $30 \mathrm{mg} / \mathrm{kg}$, as extrapolated from daily human dose using the conversion table based on body surface area. ${ }^{13}$ Paracetamol was given at a dose of $500 \mathrm{mg} / \mathrm{kg}$ based upon a pilot study.

The animals were divided into two groups. Each group consists of 10 animals. The groups were treated as following: Group I: Treated with paracetamol suspension.

Group II: Treated with paracetamol and isoniazid suspension.

Paracetamol and isoniazid were administrated orally by gastric intubation in form of suspension with gum acacia. The suspension was so prepared so as to give the desired quantity in the volume of $1 \mathrm{ml} / 100 \mathrm{~g}$ of animal weight. The duration of treatment was 2 months. Blood samples from the animals were taken for assessment of liver functions by measuring serum bilirubin, serum aspartate aminotransferase (AST) and serum alanine aminotransferase (ALT) and renal functions by measuring blood urea, serum creatinine by standard colorimetric methods before starting the drug treatment and every 15 days during treatment period. The blood was collected after overnight fasting from the retrobulbar plexus using a capillary tube under ketamine anesthesia (20 mg/kg i.p.). Plasma paracetamol concentration was measured using a colorimetric method. ${ }^{14}$ Analgesic effect of paracetamol was studied by writhing test and writhing responses were induced by intraperitoneal injection of $1 \mathrm{ml} / \mathrm{kg}$ of $4 \% \mathrm{NaCl}^{15}$ The animal reacts with a characteristic stretching behavior called writhing. Behavior includes abdominal contractions, movement of the body as a whole (particularly of hind paws), twisting of dorso-abdominal muscles, reduction in motor activity and motor in-coordination. For scoring, a writhe is indicated by stretching of the abdomen with simultaneous stretching of at least one hind limb and total duration for observation was 20 mins excluding first 5 mins.

After 2 months animals were sacrificed by using high dose of ketamine $(50 \mathrm{mg} / \mathrm{kg})$, followed by exsanguination. Liver and kidney were removed for histopathological assessment of liver and renal damage.

The data were analyzed statistically by Student's t-test, both paired and unpaired wherever applicable. $\mathrm{p}<0.05$ was considered as significant.

\section{RESULTS}

The relevant data were obtained on 0 day (pre-treatment) $15^{\text {th }}, 30^{\text {th }}, 45^{\text {th }}, 60^{\text {th }}$ day and were analyzed.

\section{Analgesic effect in animals}

Group I (paracetamol alone) and Group II (paracetamol and isoniazid) showed significant analgesic effect as comparison to control in writhing test on $15^{\text {th }}, 30^{\text {th }}, 45^{\text {th }}$, and $60^{\text {th }}$ day of the study. Similarly, analgesic effect of paracetamol was not affected by isoniazid throughout the study (Table 1).

\section{Paracetamol concentration}

The concentration of paracetamol was determined on $0,15^{\text {th }}, 30^{\text {th }}, 45^{\text {th }}$, and $60^{\text {th }}$ day of the study in both the groups. The concentration of paracetamol reached a peak after 15 days, and no statistically significant rise was seen on subsequent treatment. In Group, I paracetamol concentration did not show any significant alteration during the entire duration of the study. Paracetamol concentration on concomitant treatment with isoniazid was significantly reduced when compared with paracetamol alone group on similar days (Table 2).

\section{Effect on liver function tests}

In Group I paracetamol significantly increased the serum levels of AST and ALT on $15^{\text {th }}, 30^{\text {th }}, 45^{\text {th }}$, and $60^{\text {th }}$ when compared to pre-treatment level. This rise was maximum between $15^{\text {th }}$ and $30^{\text {th }}$ day. However, serum bilirubin level was not changed to any significant extent (Table 3).

Group II animals which were treated with a combination of isoniazid and paracetamol for a duration of 60 days showed significant increase in liver enzymes AST and ALT 
Table 1: Analgesic effect of paracetamol alone (Group I) and paracetamol with isoniazid (Group II) in comparison to control group.

\begin{tabular}{|lccccc|} 
& $\mathbf{0}$ day & $\mathbf{1 5}^{\text {th }}$ day & $\mathbf{3 0}^{\text {th }}$ day & $\mathbf{4 5}^{\text {th }}$ day & $\mathbf{6 0}^{\text {th }}$ day \\
\hline Control & $40.35 \pm 1.07$ & $41.5 \pm 1.176$ & $40 \pm 1.15$ & $40.16 \pm 1.13$ & $40.5 \pm 1.33$ \\
\hline Group I & $39.87 \pm 1.58$ & $8.33 \pm 0.42^{* * *}$ & $8.83 \pm 0.60 * * *$ & $8.5 \pm 0.56^{* * *}$ & $8.16 \pm 0.30 * * *$ \\
\hline Group II & $40.16 \pm 1.17$ & $10.83 \pm 0.75^{* * *}$ & $9.16 \pm 1.13 * * *$ & $9 \pm 0.36^{* * *}$ & $9.66 \pm 0.88^{* * *}$ \\
\hline
\end{tabular}

All values (number of writhes) are mean \pm SEM. ${ }^{*} \mathrm{p} \leq 0.05$ in comparison to control; ** $\mathrm{p} \leq 0.01$ in comparison to control; ${ }^{* * *} \mathrm{p} \leq 0.001$ in comparison to control. SEM: Standard error of mean

Table 2: Plasma concentration of paracetamol $(\mu \mathrm{g} / \mathrm{ml})$ in two groups in the study.

\begin{tabular}{|lccccc|} 
& $\mathbf{0}$ day & $\mathbf{1 5}^{\text {th }}$ day & $\mathbf{3 0}^{\text {th }}$ day & $\mathbf{4 5}^{\text {th }}$ day & $\mathbf{6 0}^{\text {th }}$ day \\
\hline Group I & $159.2 \pm 2.9$ & $161.2 \pm 3.6$ & $160.8 \pm 3.6$ & $162.8 \pm 3.6$ & $163.2 \pm 3.9$ \\
\hline Group II & $161.08 \pm 3.2$ & $135.6 \pm 2.9 * * *$ & $140.4 \pm 3.15^{* * *}$ & $135.4 \pm 2.3^{* * *}$ & $134 \pm 2 * * *$ \\
\hline
\end{tabular}

All values are mean \pm SEM. ${ }^{*} \mathrm{p} \leq 0.05 ;{ }^{*} \mathrm{p} \leq 0.01 ; * * * \mathrm{P} \leq 0.001$. SEM: Standard error of mean

on $15^{\text {th }}, 30^{\text {th }}, 45^{\text {th }}$, and $60^{\text {th }}$ when compared to pre-treatment levels and also in comparison to paracetamol alone group on similar days. Serum bilirubin remained unchanged and similar to pre-treatment level (Table 3). Histopathological study of liver showed signs of degeneration, sinusoidal congestion and occasional mononuclear cell infiltration in both groups, but severity was more in Group II. Figures 1 and 2 shows microscopic changes in liver in Group I and Group II, respectively (Table 3, Figures 1 and 2).

\section{Effects on renal function tests}

Paracetamol significantly increased the blood urea level on $15^{\text {th }}, 30^{\text {th }}, 45^{\text {th }}$, and $60^{\text {th }}$ as compared to pre-treatment level. However, serum creatinine significantly increased after $30^{\text {th }}$, $45^{\text {th }}$, and $60^{\text {th }}$ when compared to the pre-treatment levels (Table 4). However, values were within normal range.

Group II animals treated with combination of isoniazid and paracetamol for duration of 60 days showed significant increase in blood urea on $15^{\text {th }}, 30^{\text {th }}, 45^{\text {th }}$, and $60^{\text {th }}$ days when compared to pre-treatment levels and also in comparison to paracetamol alone group on similar days (Table 4). Serum creatinine significantly increased in levels as compared to pre-treatment value on $30^{\text {th }}, 45^{\text {th }}$, and $60^{\text {th }}$ day, but values were within normal range on $30^{\text {th }}$ and $45^{\text {th }}$ day a slightly more on $60^{\text {th }}$ day (Table 4). Moreover there was no significant difference in serum creatinine levels between the two groups on similar days.

Figures 3 and 4 show microscopic change (sign of mononuclear cells infiltration and congestion) and occasional glomerular degeneration in kidney in Group I and Group II respectively (Table 4, Figures 3 and 4).

\section{DISCUSSION}

Paracetamol was administered orally at the dose of $500 \mathrm{mg} / \mathrm{kg}$ for a duration of 60 days. During this period, plasma concentration was measured on $15^{\text {th }}, 30^{\text {th }}, 45^{\text {th }}$, and

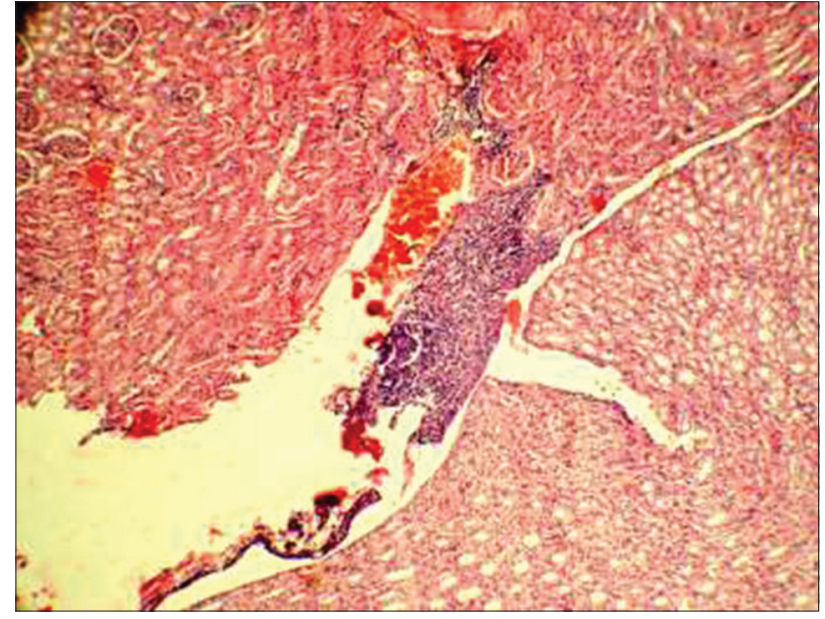

Figure 1: Histopathological changes in liver in Group I treated animals showing focal degenerative changes and sinusoidal congestion.

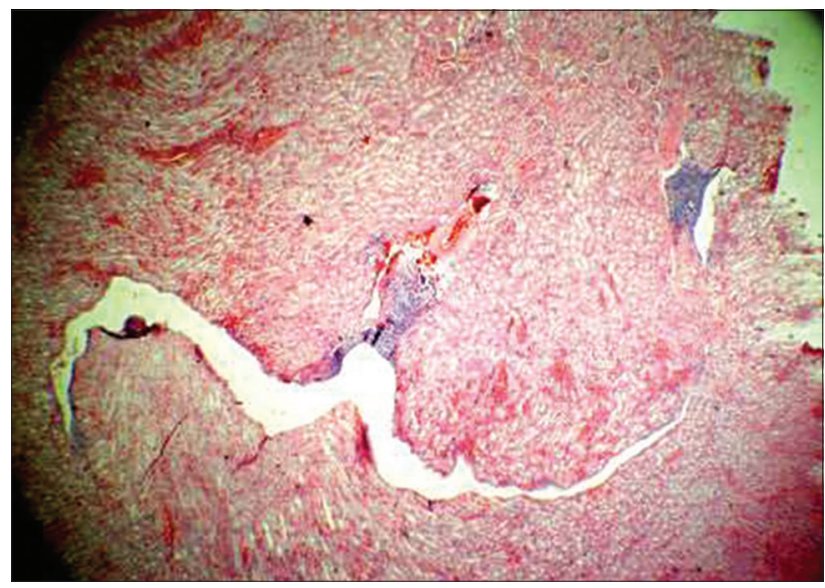

Figure 2: Histopathological changes in liver in Group II treated animals showing marked degenerative changes and sinusoidal congestion.

$60^{\text {th }}$ days of the study. Plasma concentration of paracetamol was found to be $161.2 \pm 3.6,160.8 \pm 3.6,162.8 \pm 3.6$, and $163.2 \pm 3.9 \mu \mathrm{g} / \mathrm{ml}$ on $15^{\text {th }}, 30^{\text {th }}, 45^{\text {th }}$, and $60^{\text {th }}$ day respectively. 
Table 3: Effect of paracetamol versus combination of isoniazid and paracetamol on liver function tests.

\begin{tabular}{|lcc|}
\multicolumn{4}{l}{ Group I } & Group II \\
\hline 0 day & \\
\hline AST $(\mathrm{IU} / \mathrm{ml})$ & $30.6 \pm 1.16$ & $31.4 \pm 1.5$ \\
\hline ALT $(\mathrm{IU} / \mathrm{ml})$ & $17.2 \pm 1.43$ & $18.2 \pm 1.44$ \\
\hline S. bilirubin $(\mathrm{mg} / \mathrm{dl})$ & $0.43 \pm 0.02$ & $0.43 \pm 0.02$ \\
\hline $15^{\text {th }}$ day & \\
\hline AST $(\mathrm{IU} / \mathrm{ml})$ & $64.7 \pm 3.04$ & $76.6 \pm 2.7^{* * *}$ \\
\hline ALT $(\mathrm{IU} / \mathrm{ml})$ & $41.5 \pm 1.97$ & $48.6 \pm 2.56^{* * *}$ \\
\hline S. bilirubin $(\mathrm{mg} / \mathrm{dl})$ & $0.44 \pm 0.02$ & $0.44 \pm 0.01$ \\
\hline $30^{\text {th }}$ day & & \\
\hline AST $(\mathrm{IU} / \mathrm{ml})$ & $110.4 \pm 2.8$ & $124.4 \pm 4.6^{* * *}$ \\
\hline ALT $(\mathrm{IU} / \mathrm{ml})$ & $66.8 \pm 2.2$ & $86.6 \pm 1.97^{* * *}$ \\
\hline S. bilirubin $(\mathrm{mg} / \mathrm{dl})$ & $0.47 \pm 0.03$ & $0.47 \pm 0.03$ \\
\hline $45^{\text {th }}$ day & & \\
\hline AST $(\mathrm{IU} / \mathrm{ml})$ & $123.4 \pm 3.8$ & $152 \pm 6.4^{* * *}$ \\
\hline ALT $(\mathrm{IU} / \mathrm{ml})$ & $85.2 \pm 3.3$ & $107.4 \pm 2.61^{* * *}$ \\
\hline S. bilirubin $(\mathrm{mg} / \mathrm{dl})$ & $0.44 \pm 0.02$ & $0.44 \pm 0.02$ \\
\hline $60^{\text {th }}$ day & & \\
\hline AST $(\mathrm{IU} / \mathrm{ml})$ & $130.6 \pm 2.47$ & $164.2 \pm 3.7^{* * *}$ \\
\hline ALT $(\mathrm{IU} / \mathrm{ml})$ & $118.4 \pm 5.03$ & $131.9 \pm 2.5^{* *}$ \\
\hline S. bilirubin $(\mathrm{mg} / \mathrm{dl})$ & $0.43 \pm 0.02$ & $0.43 \pm 0.02$ \\
\hline Al & & \\
\hline
\end{tabular}

All values are mean \pm SEM. ${ }^{*} \mathrm{p} \leq 0.05 ; * * \mathrm{p} \leq 0.01$;

$* * * p \leq 0.001$. SEM: Standard error of mean, AST: Aspartate aminotransferase, ALT: Alanine aminotransferase,

S. bilirubin: Serum bilirubin

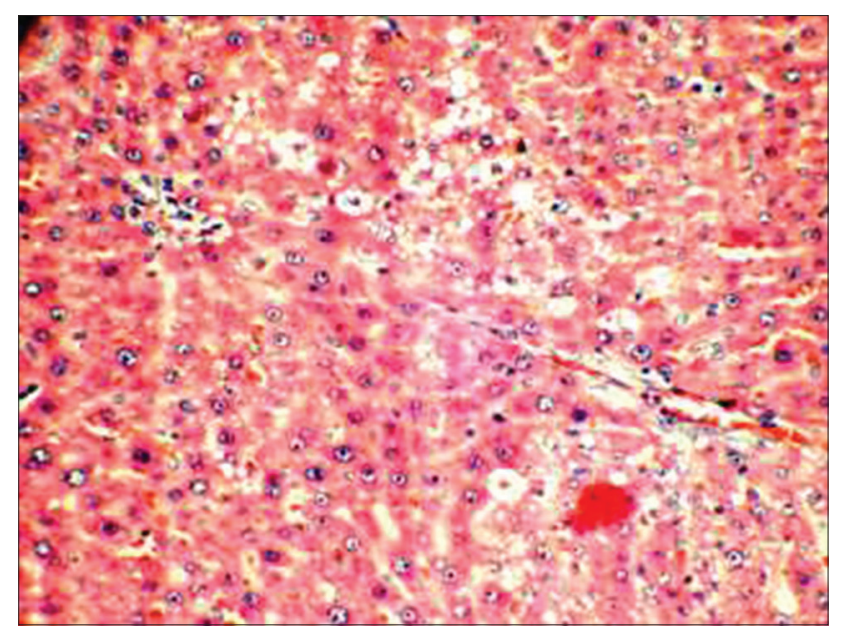

Figure 3: Histopathological changes in kidney in Group I treated animals showing mononuclear cell infiltration and congestion.

It shows that the plasma concentration remained fairly constant between 160 to $163 \mu \mathrm{g} / \mathrm{ml}$ from $15^{\text {th }}$ day onwards. Treatment beyond 2 weeks did not further increase plasma concentration of paracetamol. In isoniazid treated group of Albino rats paracetamol concentration in plasma was $135.6 \pm 2.9,140 \pm 4.3,134 \pm 2.3$ and $134 \pm 2.0$ on $15^{\text {th }}, 30^{\text {th }}, 45^{\text {th }}$, and $60^{\text {th }}$ day respectively. These values are significantly
Table 4: Effect of paracetamol versus combination of isoniazid and paracetamol on renal function tests.

\begin{tabular}{|c|c|c|}
\hline & Group I & Group II \\
\hline \multicolumn{3}{|l|}{0 day } \\
\hline Blood urea (mg/dl) & $32.2 \pm 1.4$ & $32.6 \pm 1.5$ \\
\hline S. creatinine (mg/dl) & $0.44 \pm 0.03$ & $0.43 \pm 0.04$ \\
\hline \multicolumn{3}{|l|}{$15^{\text {th }}$ day } \\
\hline Blood urea (mg/dl) & $47.6 \pm 1.8$ & $56.6 \pm 2.3^{* *}$ \\
\hline S. creatinine $(\mathrm{mg} / \mathrm{dl})$ & $0.46 \pm 0.02$ & $0.53 \pm 0.05$ \\
\hline \multicolumn{3}{|l|}{$30^{\text {th }}$ day } \\
\hline Blood urea (mg/dl) & $53.8 \pm 2$ & $65.4 \pm 3.2 * *$ \\
\hline S. creatinine $(\mathrm{mg} / \mathrm{dl})$ & $0.62 \pm 0.03$ & $0.55 \pm 0.05$ \\
\hline \multicolumn{3}{|l|}{$45^{\text {th }}$ day } \\
\hline Blood urea (mg/dl) & $57.7 \pm 1.7$ & $84 \pm 2.9 * * *$ \\
\hline S. creatinine $(\mathrm{mg} / \mathrm{dl})$ & $0.65 \pm 0.05$ & $0.66 \pm 0.04$ \\
\hline \multicolumn{3}{|l|}{$60^{\text {th }}$ day } \\
\hline Blood urea (mg/dl) & $63.2 \pm 1.5$ & $88.6 \pm 2.6 * * *$ \\
\hline S. creatinine $(\mathrm{mg} / \mathrm{dl})$ & $0.86 \pm 0.07$ & $0.97 \pm 0.05$ \\
\hline
\end{tabular}

All values are mean \pm SEM. ${ }^{*} p \leq 0.05 ; * * p \leq 0.01 ; * * * p \leq 0.001$.

SEM: Standard error of mean. S. creatinine: Serum creatinine

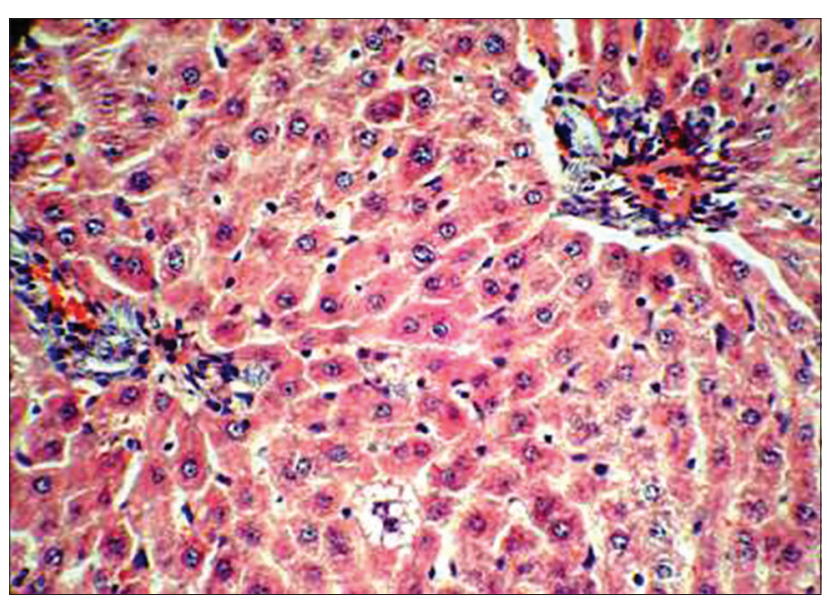

Figure 4: Histopathological changes in kidney in Group II treated animals showing mononuclear cell infiltration and congestion.

lower than the control group observed from $15^{\text {th }}$ to $60^{\text {th }}$ day of the study. The decrease in plasma concentration of paracetamol on concomitant administration of isoniazid could be due to microsomal enzyme inducing effect on cytochrome P4502E1 enzyme of liver which plays some role in metabolism of paracetamol. ${ }^{16}$

Paracetamol treatment per se or in combination with isoniazid did not induce any significant change in serum bilirubin level. However, a progressive increase in the level of enzymes such as AST and ALT was observed in both paracetamol and combination of paracetamol and isoniazid treated group. Since these enzymes are good markers of liver functions, their significant increase indicates some amount of liver dysfunction. ${ }^{16,17}$ It is further to be noted that 
increase in liver enzymes during entire length of treatment is significantly more than the control group. This clearly indicates that isoniazid treatment can potentiate hepatotoxic effect of paracetamol. Isoniazid as well as paracetamol are well-known hepatotoxic drugs. NAPQI is a toxic metabolite of paracetamol probably responsible for hepatotoxicity. The synergistic adverse effect of isoniazid and paracetamol can be explained due to microsomal enzyme induction which leads to more formation of the NAPQI from paracetamol and hepatotoxic effect of isoniazid itself. ${ }^{17}$ These biochemical changes indicating the damaging effect of paracetamol as well as combination of paracetamol and isoniazid were further confirmed by histopathological changes of liver like degenerative changes zone 1-3, sinusoidal congestion and mononuclear cell infiltration.

As far as the effects of paracetamol on kidney function are concerned, blood urea and serum creatinine levels were observed to be increased progressively in both groups when compared to pre-treatment levels. However, the values of serum creatinine were within normal range. Values of blood urea in Group II are higher than the control group. Paracetamol treatment also produced certain minor histopathological changes in kidney like congestion focal mononuclear cell infiltration and occasional glomerular degeneration. However, group treated with combination of isoniazid and paracetamol showed some signs of glomerular degeneration, mononuclear cell infiltration as well as congestion indicating the accentuation of the potential nephrotoxic effect of paracetamol by isoniazid.

It is interesting to note that though isoniazid decreased the blood concentration of paracetamol, but the analgesic effect of paracetamol remained unchanged. Probably, the other metabolite of paracetamol might be having some analgesic effect in addition to paracetamol. In addition the dose of paracetamol used may have been sufficient to produce maximal analgesic effect. Paracetamol could not be used in lower doses as it was difficult to detect in blood by the method used.

\section{CONCLUSION}

From the study, it can be concluded that in patients suffering from tuberculosis, isoniazid therapy can exacerbate the hepatotoxic and nephrotoxic effect of paracetamol if used to treat associated fever and pain. It is therefore suggested that due care should be taken, while using paracetamol in high dose or for long duration in patients who are on isoniazid treatment. However, results of this study need to be further confirmed by clinical studies.

\section{Funding No funding sources} Conflict of interest None declared Ethical approval: The study was approved by the Institutional Animal Ethics Committee

\section{REFERENCES}

1. World Health Organization. Treatment of Tuberculosis: guidelines. 4th Edition. Geneva: WHO; 2009.

2. Heifets LB. Antituberculosis drugs: antimicrobial activity in vitro. In: Drug Susceptibility in the Chemotherapy of Mycobacterial Infections. Boca Raton, FL: CRC Press; 1991: 13-57.

3. Lienhardt C, Vernon A, Raviglione MC. New drugs and new regimens for the treatment of tuberculosis: review of the drug development pipeline and implications for national programmes. Curr Opin Pulm Med. 2010;16(3):186-93.

4. Stirnimann G, Kessebohm K, Lauterburg B. Liver injury caused by drugs: an update. Swiss Med Wkly. 2010;140:w13080.

5. James L, Roberts D. Isoniazid hepatotoxicity: progress in understanding the immunologic component. Hepatology. 2014;59(3):746-8.

6. Twycross R, Pace V, Mihalyo M, Wilcock A. Acetaminophen (paracetamol). J Pain Symptom Manage. 2013;46(5):747-55.

7. GumboT,LouieA,LiuW, BrownD, Ambrose PG, Bhavnani SM, et al. Isoniazid bactericidal activity and resistance emergence: integrating pharmacodynamics and pharmacogenomics to predict efficacy in different ethnic populations. Antimicrob Agents Chemother. 2007;51(7):2329-36.

8. Yew WW. Clinically significant interactions with drugs used in the treatment of tuberculosis. Drug Saf. 2002;25(2):111-33.

9. Crippin JS. Acetaminophen hepatotoxicity: potentiation by isoniazid. Am J Gastroenterol. 1993;88(4):590-2.

10. Bennett S. Pharmacology of paracetamol and prescribing considerations. Nurse Prescr. 2013;11(1):28-33.

11. Epstein MM, Nelson SD, Slattery JT, Kalhorn TF, Wall RA, Wright JM. Inhibition of the metabolism of paracetamol by isoniazid. Br J Clin Pharmacol. 1991;31(2):139-42.

12. Nicod L, Viollon C, Regnier A, Jacqueson A, Richert L. Rifampicin and isoniazid increase acetaminophen and isoniazid cytotoxicity in human HepG2 hepatoma cells. Hum Exp Toxicol. 1997;16(1):28-34.

13. Paget GE, Barnes AL. Toxicity tests. In: Laurence DR, Bacharach AL, editors. Evaluation of Drug Activities: pharmacometerics. London, New York: Academic Press; 1964: 135-66.

14. Glyn JP, Kendal SE. Paracetamol measurement. Lancet. 1975;1(7916):1147-8.

15. Patel DK, Shah KH, Tank MK. Evaluation of hepatoprotective activity of polyherbal formulation in paracetamol induced hepatotoxicity in rats. J Pharm Sci Rev Res. 2013;22(1):134-9.

16. Andrade RJ, Lucena MI, Melgarejo F, García-Escaño MD. Hepatotoxicity caused by isoniazid or by paracetamol. Gastroenterol Hepatol. 1998;21(6):314-5.

17. Chien JY, Peter RM, Nolan CM, Wartell C, Slattery JT, Nelson SD, etal. Influence of polymorphic N-acetyltransferase phenotype on the inhibition and induction of acetaminophen bioactivation with long-term isoniazid. Clin Pharmacol Ther. 1997;61(1):24-34.

doi: 10.5455/2319-2003.ijbcp20141007

Cite this article as: Dahiya N, Sharma S, Khadka A, Brashier DS, Gupta AK, Sharma AK. An experimental study on the effect of isoniazid on the efficacy, plasma concentration and toxicity of paracetamol in Albino rats. Int J Basic Clin Pharmacol. 2014;3:807-11. 